Journal of The Magnetics Society of Japan Vol. 13, Supplement, No. S1 (1989)

(C) 1989 by The Magnetics Society of Japan

\title{
LOW TEMPERATURE FERRITE FILM PREPARATION BY FERRITE PLATING TECHNIQUE
}

\author{
Tomoyuki ITOH, Masanori ABE and Yutaka TAMAURA-
}

\author{
Department of Physical Electronics and Department of Chemistry, \\ Tokyo Institute of Technology, 0-Okayama, Meguro-ku, \\ Tokyo 152, Japan.
}

\begin{abstract}
Ferrite plating facilitates formation of polycrystalline spinel ferrite films $\left(\mathrm{Fe}_{3}-\mathrm{M}_{\mathbf{x}} \mathrm{O}_{4}, \mathrm{M}=\mathrm{Fe}, \mathrm{Co}, \mathrm{Ni}, \mathrm{Zn}\right.$, etc.) at low temperature in an aqueous solution. Though prepared at low temperature $\left(<90^{\circ} \mathrm{C}\right)$, the magnetic properties of the films are as good as those in bulk samples, the ferrite plating opening the door to new ferrite film devices using a non-heat-resistant substrate. In this paper we describe the principle and methods of ferrite plating, and report structural and magnetic properties of the films as well as the deposition rate of the films in connection with the conditions under which the ferrite plating is performed.
\end{abstract}

\section{INTRODUCTION}

Ferrite plating invented by the authors facilitates the formation of crystalline spinel films in an aqueous solution below 90 ${ }^{\circ} \mathrm{C}[1]-[4]$. While conventional electro or electroless plating make metal films, our ferrite plating makes oxide films with spinel structure. The plated films of the spinel, $\quad \mathrm{Fe}_{3-\mathbf{x}} \mathrm{M}_{\mathbf{x}} \mathrm{O}_{\mathbf{4}}$, can contain various transition metal ions (e.g., M=Ni, Co, Zn, $\mathrm{Mn}$, and $\mathrm{Cr}$; or mixture of there metal ions). Though prepared at low temperature, the ferrite plating films are good in crystallinity, having magnetic properties as good as those of bulk samples. Thus the ferrite plating opened the door to make the new ferrite film devices: magnetic capsule toner and carrier for zerography and magnetography in which polymer microspheres are coated with ferrite [11], and nonreciprocal ferrite devices such as circulator fabricated on GaAs MMIC which deteriorates when heated above $300{ }^{\circ} \mathrm{C}$ [5], [8].

The ferrite plating films show good affinity with such organic materials as dextran and sucrose [7]. Fixing a enzyme (urease or glucose oxidase) on the $\mathrm{Fe}_{3} \mathrm{O}_{4}$ films intermediated by dextran layer, we have successfully made biosensors which detect biomaterial (i.e., urea or glucose) in a biosolution [11].

This paper describes the principle and experimental methods of ferrite plating, and presents the structure and magnetic properties of the films of $\mathrm{Fe}_{3-x} \mathrm{Co}_{\mathbf{x}} \mathrm{O}_{4}$ $(\mathrm{x} \leq 0.43), \quad \mathrm{Fe}_{3-\mathrm{x}} \mathrm{Ni}_{\mathbf{x}} \mathrm{O}_{4}$ ( $\left.\mathrm{x} \leq 0.93\right)$, and $\mathrm{Fe}_{3-\mathrm{x}} \mathrm{Zn}_{\mathrm{x}} \mathrm{O}_{4} \quad(\mathrm{x} \leq 0.8)$ prepared by the ferrite plating.

\section{PRINCIPLE OF FERRITE PLATING}

A substrate with OH-groups on the surface is soaked in a reaction solution containing $\mathrm{Fe}^{2+}$ and other metal ions such $\mathrm{Co}^{2+}, \mathrm{Ni}^{2+}, \mathrm{Mn}^{2+}$ and $\mathrm{Zn}^{2+}[1]$. Then the metal ions are adsorbed on the surface intermediated by the OH-groups. By introducing an oxidizing reagent, such as air, $\mathrm{NO}^{3-}, \mathrm{NO}^{2-}, \mathrm{ClO}^{4-}$ or anodic current (which is applicable only for $\mathrm{Fe}_{3} \mathrm{O}_{4}$ film with metallic conductivity), into the solution, some of the adsorbed $\mathrm{Fe}^{2+}$ ions are oxidized to $\mathrm{Fe}^{3 *}$. This causes ferrite formation reaction. Since the ferrite layer thus formed has also OH-groups on the surface, the ferrite formation reaction is repeated to grow the ferrite film. The ferrite formation occurs in the aqueous solution at $\mathrm{pH}=6-11$ and $\mathrm{T}>60^{\circ} \mathrm{C}$.

\section{EXPERIMENTAL}

\subsection{Preparation of Aqueous Solution}

The reaction solution is prepared from $\mathrm{FeCl}_{2}, \mathrm{CoCl}_{2}, \mathrm{NiCl}_{2}$, and $\mathrm{ZnCl}_{2}$ by dissolving them together with $\mathrm{CH}_{3} \mathrm{COONH}_{4}$ (which works as a pH buffer and also a complexing agent) in distilled water [2]-[4], [6]. The $\mathrm{pH}$ value of the solution is adjusted to a desired value (5-8) by adding $\mathrm{NaOH}$ or $\mathrm{NH}_{3}$ solution. 
The oxidizing solution used in this study is prepared by dissolving $\mathrm{NaNO}_{2}$ and $\mathrm{CH}_{3} \mathrm{COONH}_{4}$ in distilled water.

\subsection{Plating Methods}

We have developed several methods for performing ferrite plating. In the early stage of our study, we performed the ferrite plating by "air-bubbling" and "rotating disc" methods [2], in which air is used as an oxidizing reagent. In these methods film deposition rate is very low $(2 \mathrm{~nm} / \mathrm{min})$ and the film quality is deteriorated, because the ferrite powders formed in the reaction solution stick to the filin surface. In order to correct the defects, we invented "thin liquid-film" method, in which the reaction and oxidizing solution are flowed through the narrow space between the substrate surface and the cell wall (Fig. 1 (a)) [3]. The ferrite particles formed in the solution are rinsed off, prevented from sticking to the film surface. This improves the film quality.

(a)

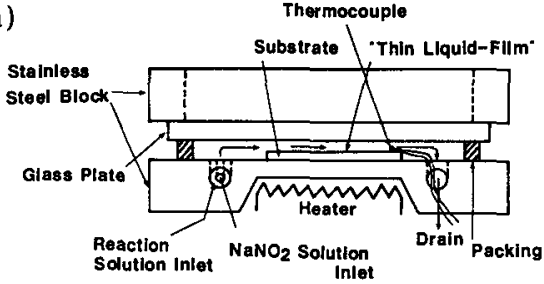

(b)

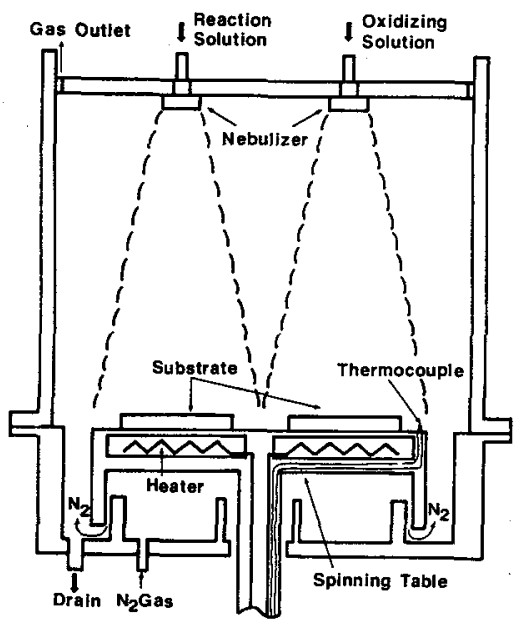

Fig. 1 (a) "Thin liquid-film" method [3] and (b) "spin-spray" [4], [6] method for ferrite plating.
Furthermore, by using $\mathrm{NaNO}_{2}$ solution instead of air as the oxidizing solution, we have improved the film deposition rate by a factor 8-10. Using the $\mathrm{NaNO}_{2}$ solution also facilitates a precise control of the oxidizing rate in the ferrite formation reaction.

In order to further improve the film quality and to extend the size of the substrate up to 8 " diameter, we invented "spin-spray" method [4], [6]. The reaction and oxidizing solution are simultaneously sprayed onto the spinning substrate as shown in Fig. 1 (b). This facilitated formation of ferrite films with a mirror luster on a $8^{\prime \prime}$ glass disc.

To increase the solubility limit of such particular metal ions as $\mathrm{Ni}^{2+}$ and $\mathrm{Mn}^{2+}$ in the plated film, we have performed the plating at elevated temperatures $\mathrm{T}=100-200$ ${ }^{\circ} \mathrm{C}$ [12]. We call this method as "hydrothermal" method, because the pressure inside the reaction cell (which is essentially similar as is used in the "thin liquid-film" method) is kept sufficiently high $\left(15-20 \mathrm{kgf} / \mathrm{cm}^{2}\right)$ to prevent the mixed aqueous solution from boiling.

\section{DEPOSITION RATE AND PROPERTY OF FILM}

\subsection{Chemical Composition of Filll}

As Fig. 2 shows, the chemical composition of the plated films deviates from that of the reaction solution [6]. The $\mathrm{Zn}$ composition, $\mathrm{x}$, in $\mathrm{Fe}_{\mathbf{3}-\mathbf{x}} \mathrm{Zn}_{\mathbf{x}} \mathrm{O}_{4}$ film (curve (a)) is extremely larger than that in the reaction solution, while $\mathrm{Ni}$ composition, $\mathrm{x}$, in $\mathrm{Fe}_{3-x} \mathrm{Ni}_{x} \mathrm{O}_{4}$ film (curve (b)) is much smaller than that in the solution, though

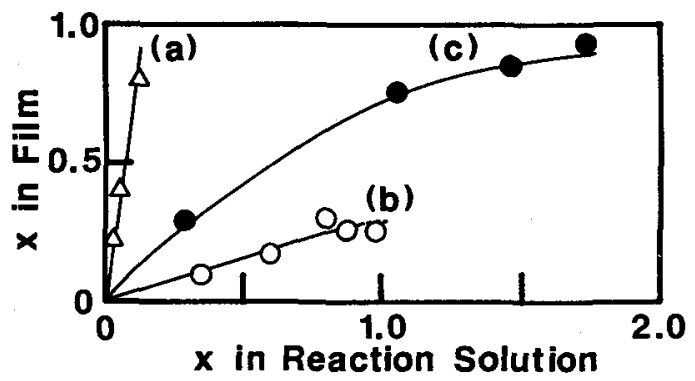

Fig. 2 Composition $x$ in films of (a) $\mathrm{Fe}_{3-\mathrm{x}} \mathrm{Zn}_{\mathbf{x}} \mathrm{O}_{4}$ (plating conditions: $\mathrm{pH}=6.9, \mathrm{~T}=80$ C), (b) $\mathrm{Fe}_{3-\times} \mathrm{Ni}_{\mathbf{x}} \mathrm{O}_{4}\left(\mathrm{pH}=6.9, \mathrm{~T}=80^{\circ} \mathrm{C}\right)$ and (c) $\mathrm{Fe}_{3-x} \mathrm{Ni}_{x} \mathrm{O}_{4}\left(\mathrm{pH}=7.0, \mathrm{~T}=200{ }^{\circ} \mathrm{C}\right)$ plotted as a function of $x$ in reaction solution. 
all the films are plated on the same conditions (i.e., $\mathrm{pH}=6.9$ and $\mathrm{T}=80^{\circ} \mathrm{C}$ ). This is because at $\mathrm{pH}=6.9$ the rate of the adsorption of the $\mathrm{Zn}^{2+}\left(\mathrm{Ni}^{2+}\right)$ ions is much higher (smaller) than that of the $\mathrm{Fe}^{2+}$ ions.

The $\mathrm{Ni}$ concentration is increased by elevating the plating temperature from $80^{\circ} \mathrm{C}$ (curve (b)) to $200^{\circ} \mathrm{C}$ (curve (c)) [12]. This is because the number of the $\mathrm{Fe}^{2+}$ ions, which compete with the $\mathrm{Ni}^{2+}$ ions in entering into the spinel lattice, decreases at the high temperature where the rate of the $\mathrm{Fe}^{2+}$ $\rightarrow \mathrm{Fe}^{\mathrm{a}+}$ oxidization increases.

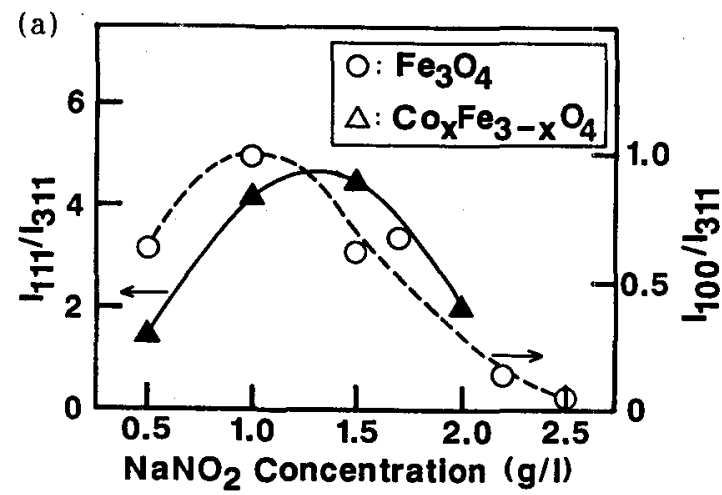

(b)

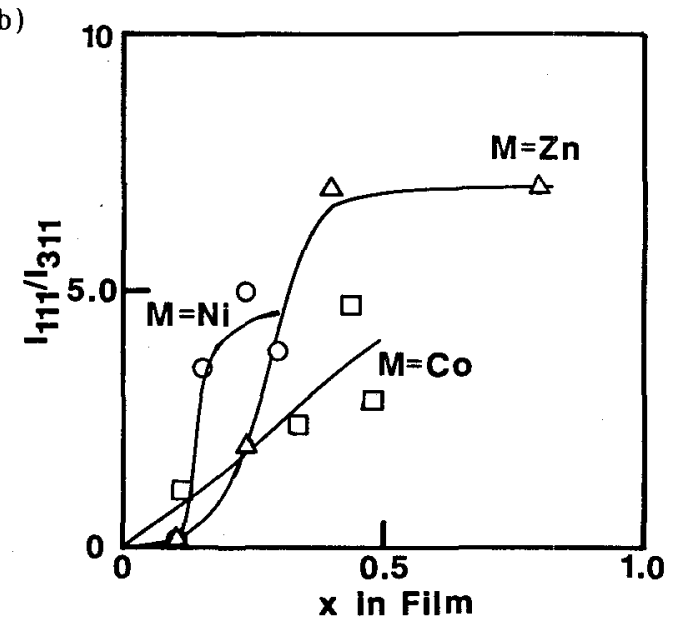

Fig. 3 (a) $X$-ray line intensity ratios $\mathrm{I}_{100} / \mathrm{I}_{311}$ and $\mathrm{I}_{111} / \mathrm{I}_{311}$ for $\mathrm{Fe}_{3} \mathrm{O}_{4}$ and $\mathrm{Fe}_{3-x} \mathrm{Co}_{x} \mathrm{O}_{4} \quad(\mathrm{x}=0.43+0.03)$ films, respectively, plotted vs. $\mathrm{NaNO}_{2}$ concentration in oxidizing solution [10]. (b) X-ray line intensity ratio $I_{111} / I_{311}$ for $\mathrm{Fe}_{3-x} \mathrm{M}_{\mathbf{x}} \mathrm{O}_{4}$ $(\mathrm{M}=\mathrm{Ni}, \mathrm{Co}, \mathrm{Zn})$ films, plotted vs. $\mathrm{x}$ in film $[10],[6]$.
4.2 Deposition Rate and Structure of Film All the plated films are polycrystalline with spinel structure.

The deposition rate of $f$ ill increases as the $\mathrm{NaNO}_{2}$ concentration in the oxidizing solution increases. For good quality film of single phase spinel, we get maximum rate of $30 \mathrm{~nm} / \mathrm{min}$ and $20 \mathrm{~mm} / \mathrm{min}$ by the "thin liquidfilm" [3] and "spin-spray" method [4], respectively.

As Fig. 3 (a) shows, the film of $\mathrm{Fe}_{3} \mathrm{O}_{4}$ and $\mathrm{Fe}_{3-\mathbf{x}} \mathrm{Co}_{\mathbf{x}} \mathrm{O}_{4}$ exhibit preferential crystallographic orientation along (100) and (111) planes, respectively, parallel to the surface. This texture is most prominent when the $\mathrm{NaNO}_{2}$ concentration is 1.0 and $1.5 \mathrm{~g} / \mathrm{l}$, respectively [10]. Not only $\mathrm{Co}^{2+}$ but also $\mathrm{Ni}^{2+}$ and $\mathrm{Zn}^{2+}$ causes the (111) texture as their concentrations in the film increase (Fig. 3 (b) ) [6].

\subsection{Magnetic Properties}

As measured by a vibrating sample magnetometer, the magnetization in all the plated films lies in the film plane due to demagnetizing field. The values of the saturation magnetization in the $\mathrm{Fe}_{3-x} \mathrm{M}_{\mathbf{x}} \mathrm{O}_{4}$ ( $\mathrm{M}=\mathrm{Fe}, \mathrm{Co}, \mathrm{Ni}$, and $\mathrm{Zn}$ ) films coincide with those expected for the bulk samples [3], [6]. The ferrite plating films have good crystallinity, even though they are prepared at low temperature $\left(<90^{\circ} \mathrm{C}\right)$.

As shown in Fig. 4, the coercive force parallel to the film plane in NiZn-ferrite [5], magnetite [4], and Co-ferrite [10] films are 31 oe, $160 \mathrm{Oe}$, and $6150 \mathrm{e}$, respectively. The strong coercive forces in the magnetite and Co-ferrite films are ascribed to the $\mathrm{Fe}^{2+}$ and $\mathrm{Co}^{2+}$ ions with anisotropic electron clouds. Thus we can prepare soft and hard magnetic films by ferrite plating.

When dextran $\left(\left(\mathrm{C}_{6} \mathrm{H}_{10} \mathrm{O}_{5}\right)_{n}, \quad \mathrm{n}=1200-1800\right)$ solution is added to the reaction solution in the $\mathrm{Fe}_{3} \mathrm{O}_{4}$ plating by "spin-spray" method, coercive force as well as saturation magnetization reduces [9]. Dextran reduces and increases the amounts of $\mathrm{Fe}^{2+}$ and $\mathrm{Fe}^{3+}$, respectively, changing the chemical composition of the film from $\mathrm{Fe}_{3} \mathrm{O}_{4}$ to $\gamma-\mathrm{Fe}_{2} \mathrm{O}_{3}$.

\section{CONCLUDING REMARKS}

By ferrite plating we have made magnetic films of compositions $\mathrm{Fe}_{3-\mathrm{x}} \mathrm{M}_{\mathrm{x}} \mathrm{O}_{4}$, 

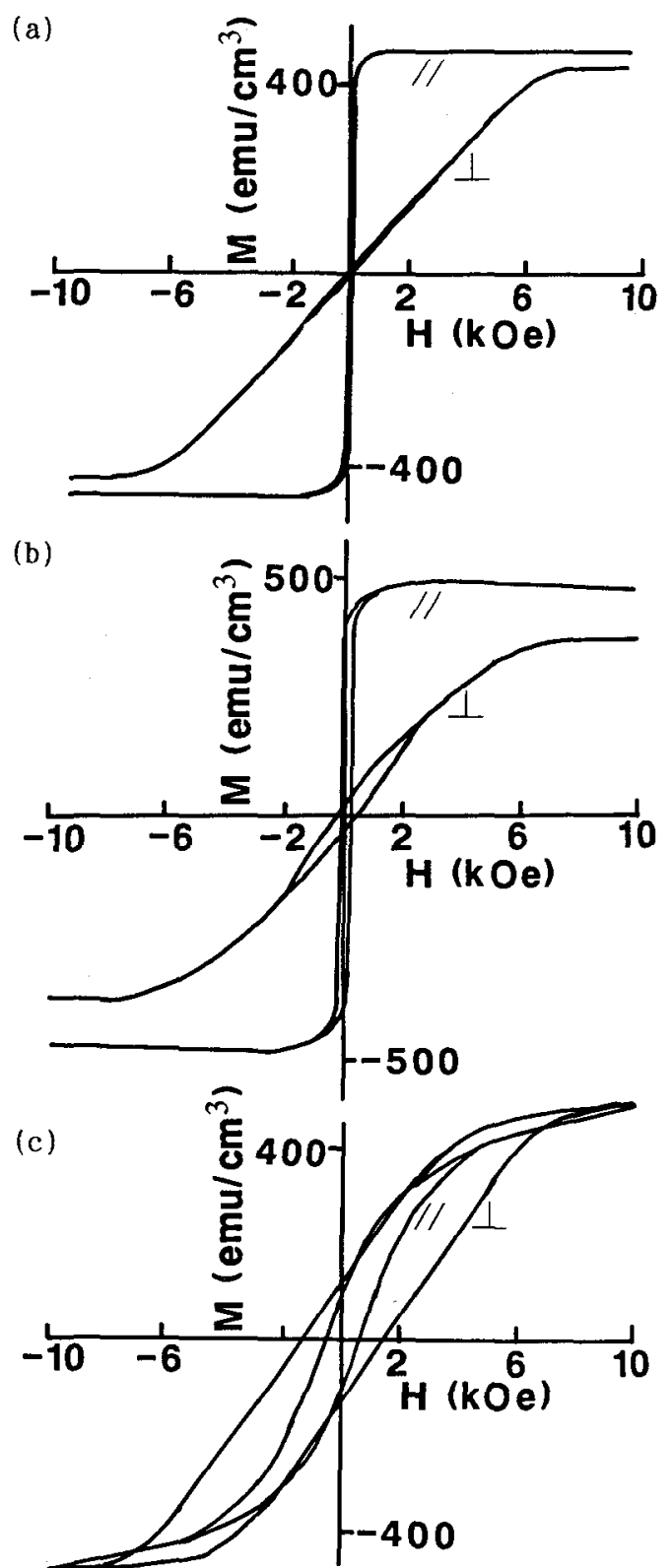

Fig. 4 Magnetization curves for (a)

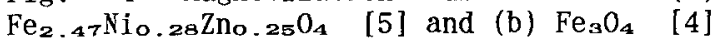
films formed by "spin-spray" method, and (c) $\mathrm{Fe}_{2.57} \mathrm{COO}_{4.4} \mathrm{O}_{4}$ [10] films formed by "thin liquid-film" method, measured parallel (//) and perpendicular ( $\perp$ ) to the film plane. where $M=F e, C o, ~ N i, M n$, and $\mathrm{Zn}$. The films are polycrystalline with spinel structure. They tend to exhibit a (100) or (111) texture depending on their chemical composition and the concentration of $\mathrm{NaNO}_{2}$ in the oxidizing solution. Though prepared at low temperature $\left(<90^{\circ} \mathrm{C}\right)$, the films have magnetic properties as good as those in bulk samples, showing that the films are crystallized well.

There are several methods to perform the ferrite plating, among which the "spinspray" and the "thin liquid-film" methods are most advantageous to get good quality films. The latter is extended to the "hydrothermaI" method, in which the films are plated at $\mathrm{T}=100-200^{\circ} \mathrm{C}$ and $\mathrm{P}=10-$ $15 \mathrm{kgf} / \mathrm{cm}^{2}$. This method increase the solubility limit of such particular ion as $\mathrm{Ni}^{2}$ + in the spinel much.

The deposition rate of the film in the ferrite plating is $20-30 \mathrm{~nm} / \mathrm{min}$. We found recently that we can enhance the deposition rate more than several times when the substrate is heated optically instead of using a resistance heater. We call this "light-enhanced" method, which we expect to bring about a new development in the ferrite plating technique.

\section{REFERENCES}

[1] M. Abe and Y. Tamaura, J. Appl. Phys., "Ferrite plating in aqueous solution: New technique for preparing magnetic thin film" Vol.55, pp.2614-2616, 15 March 1984.

[2] M. Abe and Y. Tamaura, Advances in Ceramics, "Ferrite Plating in Aqueous Solution for Preparing Magnetic Thin Film", Vol.15, pp.639-645, 1985.

[3] M. Abe, Y. Tamaura, Y. Gotoh, N. Kitamura and M. Gomi, J. Appl, Phys., "High speed deposition of high-quality ferrite films from aqueous solution at low temperature $\left(<90^{\circ} \mathrm{C}\right) "$, Vol.61, pp. 3211-3213, 15 April 1987.

[4] M. Abe, Y. Tamaura, M. Oishi, T. Saitoh and M. Gomi, IEEE Trans. Mag., "PLATING OF FERRITE FILM ON 8" DISC AT $70^{\circ} \mathrm{C}$ BY "SPRAY-SPIN-COATING" METHOD", Vol.MAG23, pp.3432-3434, September 1987.

[5] M. Abe, T. Itoh, Y. Tamaura, Y. Gotoh, and M. Gomi, IEEE Trans. Mag. , "FERRITE PLATING ON GaAs FOR MICROWAVE MONOLITHIC INTEGRATED CIRCUIT", 
Vol.MAG-23, pp.3736-3738, September 1987.

[6] T. Itoh, M. Abe and Y. Tamaura, Jpn. J. Appl. Phys., "Ferrite Plating of (Fe, $\mathrm{Ni}, \mathrm{Zn})_{3} \mathrm{O}_{4}$ Films in Aqueous Solution by an "Improved" Spray-Spin-Coating Method", Vol.27, pp. 839-842, May 1988.

[7] M. Abe, T. Itoh, Y. Tamaura and $M$. Gomi, J. Appl. Phys., "Ferrite-organic multilayer film for microwave monolithic integrate circuits prepared by ferrite plating based on the sprayspin-coating method", Vol.63, pp.37743776 , April 1988 .

[8] S. H. Talisa, K. C. Yoo, M. Abe and T. Itoh, J. Appl. Phys., "FMR studies of spin-spray $\mathrm{Ni}-\mathrm{Zn}$ ferrite films", Vol.64, pp.5819-5821, 15 November 1988.

[9] T. Itoh, M. Abe and Y. Tamaura, J. de Physique, "FERRITE FILMS WITH ORGANIC ADDITIVES PREPARED BY FERRITE PLATING TECHNIQUE", Colloque C8, pp.C8-2015 C8-2016, decembre 1988 .

[10] Y. Goto, Y. Tamaura, M. Abe and $M$. Gomi, IEEE Trans. Mag. in Japan, "Improvement in Deposition Rate and Quality of Films Prepared by "Thin Liquid-Film" Ferrite Plating Method", Vol.3, pp. 159-165, February 1988.

[11] M. Abe, T. Itoh and K. Yoshimura, "NEW APPLICATION OF FERRITE PLATING TECHNIQUE", presented at ICF-5 (Bombay, India), to be published in Advances in Ceramics.

[12] T. Itoh, M. Abe, T. Sasao and Y. Tamaura, "FERRITE PLATING OF $\mathrm{Fe}_{3} \mathrm{O}_{4}$ AND $\mathrm{Fe}_{3-\times} \mathrm{Ni}_{\times} \mathrm{O}_{4}$ FILMS AT 100-200 'C", presented at Intermag ' 89 , to be published in IEEE Trans. Mag. 